\title{
INFLUENCE OF MINERAL NITROGEN AND FARMYARD MANURE FERTILIZERS ON SOME RICE DISEASES AND INSECTS
}

\author{
Badr, E.A.S. ${ }^{1}$ and M.M. El-Habashy ${ }^{2}$
}

1- Rice Pathology Dept., Plant Pathology Res. Inst. Agric., Res. Center.

2- Rice Res. \& Training Center (RRTC), Field Crops Res. Inst. Agric., Res. Center.

\begin{abstract}
Experiments were conducted at the experimental farm of Rice Research and Training Center, Sakha in 2004 and 2005 to evaluate the effect of nitrogen fertilizer sources as farmyard manure FYM and / or urea at different rates on rice blast, white tip nematode and rice stem borer on seven rice cvs. The considered cultivars were Giza 171, Giza 176, Giza 177, Giza 178, Giza 181, Skha 101 ans Sakha 104 fertilized with $30 \mathrm{~m}^{3} \mathrm{FYM}, 20 \mathrm{M}^{3} \mathrm{FYM}, 10 \mathrm{~m}^{3} \mathrm{FYM}+20 \mathrm{~kg} \mathrm{~N}$ urea, $40 \mathrm{~kg} \mathrm{~N}$ urea, $60 \mathrm{~kg} \mathrm{~N}$ urea and $80 \mathrm{~kg} \mathrm{~N}$ urea/fed. Results showed that leaf and panicle blast infection was not observed on Giza 177, Giza 178 and Giza 181 while Giza 171 had the highest infection followed by Giza 176, Sakha 104 and Sakha 101. Blast isolate obtained from Sakha $104 \mathrm{cv}$. was identified as IB 45, while that obtained from Sakha $101 \mathrm{cv}$. was identified as IG1. White tip nematode was affected by kind and amount of nitrogen application. The highest infection was detected on Giza 171 followed by Giza 177 and Sakha 101, while Giza 176, Giza 178 and Giza 181 were the lowest infected cultivars, whereas no infection was found on Sakha 104. High rates of organic or inorganic nitrogen led to an increase in susceptibility of cultivars to white tip nematode. The rice stem borer infestation was highest at the highest rate of mineral nitrogen $(80 \mathrm{~kg} / \mathrm{fed}$ ), followed by $60 \mathrm{~kg} \mathrm{~N} /$ fed or application of 30 ton FYM / fed. The lower rates of mineral nitrogen $(40 \mathrm{~kg} / \mathrm{fed})$ resulted in less borer infestation.
\end{abstract}

\section{INTRODUCTION}

Rice blast disease caused by Pyricularia grisea Cavara, is one of the most important diseases of rice crop in all rice growing countries. It is considered the most important disease affecting rice crop in Egypt (AbdelHak et al., 1982; Sehly, 1982; and El-Kazzaz et al. 1990). It has been known that blast infection increases with the extensive use of nitrogen fertilizer, particularly the organic ones (Shatla et al. 1983; El-Refaei et al. 1985), Sivakumar (1988) reported that out of 187 rice cultivars and varieties screened to white tip nematode, A. besseyi, TPS-1, TPS-2, AS-19903, HKR1, PTB-1, PTB-4 and Madhuri were moderately resistant. Popova et al.. (1989) evaluated more than 200 rice collection and samples. $92 \%$ of the rice hybrids and varieties were highly susceptible to $A$. besseyi, highlighting the need for the inclusion of resistant forms into the selection process. Five highly resistant collection samples were identified for further study. Silveira et al.. (1990) reported that the lines LS 85-10, 81-22, 82-279, 81-67, 8-55, 82-72, 82-76 and $82-8$ of rice were considered tolerant to $A$. besseyi in greenhouse tests. The lines LS 82-52, 79-188, 84-242 and LS 81-25 were susceptible. Soil organic matter plays an important role in soil fertility. Its consider the major source of nutrients specially in rice nutrition Chu et al.., (1978). Sharma and Mittra (1988 \& 1991) found that the application of farmyard manure at the rate of $10 \mathrm{t} / \mathrm{ha}$ at 
transplanting increased grain yield as much as the application of $30 \mathrm{~kg} \mathrm{~N} / \mathrm{ha}$. They found also that increasing the rate of farmyard manure application up to $15 \mathrm{t} / \mathrm{ha}$ increased grain yield significantly. Thakur et al. (1995) reported that yields of rice grain and straw increased significantly due to the application of organic manures.

On the other hand, rice plants are attacked by several insect pests, and rice stem borer, Chilo agamemnon (Bles.) is the most important one in Egypt. Yield losses due to rice stem borer was estimated as $6 \%$ (Isa, 1989). The infestation by this pest is affected by cultural practices, and fertilizer is one of these factors specially nitrogen (Subramanian et al. 1977 and Sherif 1980). Organic fertilizer is a very important factor that affect the infestation by rice stem borer. Magdoff and van Es (2000) indicated that farming practices that cause nutrition imbalance can lower pest resistance. Also, soil nutrient availability not only affects the amount of damage that plants receive from herbivores but also the ability of plants to recover from herbivores (Meyer, 2000).

This research was conducted in 2004 and 2005 seasons to study the effect of mineral nitrogenous fertilizers and farmyard manure on blast and white tip nematode infection, as well as rice stem borer infestation.

\section{MATERIALS AND METHODS}

This experiment was carried out at the experimental farm of Rice Research and Training Center (RRTC), Sakha, in 2004 and 2005 rice growing seasons to study the effect of mineral nitrogenous fertilizer and farmyard manure on blast, white tip nematode infection and rice stem borer in seven rice cultivars. Considered cultivars were: Giza 171, Giza 176, Giza 177, Giza 178, Giza 181, Sakha 101 and Sakha 104. A split plot design with four replicates was adopted. The main treatments were assigned for the rice cvs., while sub plots were used for nitrogen sources and rates. The mineral nitrogen was used as urea $(46.5 \% \mathrm{~N})$ at rates of 40,60 , and 80 units of nitrogen per feddan. Half of the dose was incorporated into the soil just before buddling, while the other half was added 30 days after transplanting. The rates of farmyard manure (FYM) were 20 and $30 \mathrm{~m}^{3} / \mathrm{fed}$ incorporated and plowed into the soil prior to the last plough. An additional treatment was applied as $20 \mathrm{~kg}$ mineral nitrogen $+10 \mathrm{~m}^{3} \mathrm{FYM} / \mathrm{fed}$. The plot size measured 2 x $5 \mathrm{M}$, which comprised 10 rows with $20 \times 20 \mathrm{~cm}$ spacing between rows and hills. Twenty-eight day old seedlings were transplanted.

\section{Blast infection:}

\subsection{Greenhouse test:}

The seven cultivars in addition to eight international differential cvs. (Atkins et al. 1974) were evaluated for blast reaction under greenhouse conditions using two blast isolates collected from Sakha 104 and Sakha 101 rice cultivars. All the materials were seeded in plastic trays $(30 \times 20 \times 15 \mathrm{~cm})$. Each tray (as one replicate) comprised 20 rows having seven cultivars, eight international differential varieties and Giza 159 as a rice susceptible check to blast. The trays were kept in the greenhouse at $25-30{ }^{\circ} \mathrm{C}$ and fertilized with urea $46.5 \%$ nitrogen ( $5 \mathrm{~g} /$ tray). The isolates were grown and multiplied on 
banana medium and incubated at $28^{\circ} \mathrm{C}$. The spores were harvested at a density of at least 25 spores / microscopic field. Rice seedlings of 20 days old were inoculated by spraying with the spore suspension $\left(5 \times 10^{4}\right.$ spores $\left./ \mathrm{ml}\right)$ of each isolate in the evening to avoid the retarding effect of sunlight on both spore germination and germ tube growth. The reaction of the tested entries to blast infection was estimated according to IRRI scale (1996) seven days after inoculation.

\subsection{Blast infection determination under field conditions:}

Samples of rice leaves were taken four times at 15-day intervals starting from thirty days after transplanting. Each sample consisted of one hundred leaves randomly collected from each plot. Percentage of the infected leaves was calculated, while severity of infection was estimated by counting the total number of type (4) blast lesions / 100 leaves. Neck rot infection was estimated by collecting one hundred panicles from each plot, and the severity was calculated using the formula adopted by Townsend and Huberger (1943).

\section{White tip nematode:}

Severity of white tip nematode infection was evaluated by counting number of infected leaves per $\mathrm{m}^{2}$ in each plot, just before heading or at late booting to count larvae, 10 seedlings (just before transplanting) were collected from each nursery treatment, washed, cut into small pieces and placed with water in a watch glass. Twenty-four hours later, the number of nematode larvae was counted using the stereoscopic microscope. At maturity stage, five infected and five healthy panicles were collected from each plot to count the harboured nematode larvae as previously mentioned.

\section{Rice stem borer infestation:}

Three weeks before harvest, five hills were cut from each plot and the total number of tillers was recorded. White heads were separated, counted and percentage of rice stem borer, Chilo agamemnon infestation was calculated.

\section{Grain yield:}

Grain yield of each plot was estimated by harvesting all plants in the plot except the outer row from each side. The plants were threshed, and grain weight was recorded and adjusted to $14 \%$ moisture content, then the yield was calculated as $\mathrm{t} / \mathrm{feddan}$.

\section{RESULTS AND DISCUSSION}

1. Blast infection:

\subsection{Greenhouse test:}

This test was achieved using two isolates collected from Sakha 104 (No1) and Sakha 101 (No 2). Data in Table (1) show that isolate No (1) was virulent to Giza 171, Giza 176 and Sakha 104 but avirulent to Giza 178, Giza 181 and Sakha 101. Isolate No (2) was virulent to Giza 171, Giza 176 and Sakha 101, while Giza 177, Giza 181 and Sakha 104 behaved as moderately 
resistant. However, Giza 171 proved to be highly susceptible to isolate (2). Data in Table (2) show that isolate No.1 infected international differential varieties Zenith, Usen, Ci 8970s and Calora, and identified as race (IB45) which isolated from Sakha 101 infected international differential varieties; $\mathrm{Ci}$ 8970 s and Calora and identified as IG1.

Table (1): Reaction of commercial rice varieties to Pyricularia grisea isolates obtained from Sakha 101 and sakha 104

\begin{tabular}{|c|c|c|}
\hline Cultivar & $\begin{array}{c}\text { Isolate No. } 1 \text { obtained from } \\
\text { Sakha104 }\end{array}$ & $\begin{array}{c}\text { Isolate No. } 2 \text { obtained from } \\
\text { Sakha101 }\end{array}$ \\
\hline Giza 171 & 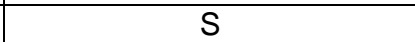 & HS \\
\hline Giza176 & S & $S$ \\
\hline Giza177 & $\mathrm{R}$ & MR \\
\hline Giza178 & $\mathrm{R}$ & $\mathrm{R}$ \\
\hline Giza182 & $R$ & MR \\
\hline Sakha 101 & $\mathrm{R}$ & HS \\
\hline Sakha 104 & $\mathrm{HS}$ & MR \\
\hline
\end{tabular}

R = Resistant, MR= Moderately Resistant, S= Susceptible, HS= Highly Susceptible

Table (2): Reaction of international differential rice varieties to Pyricularia grisea isolates obtained from Sakha 101 and sakha 104

\begin{tabular}{|l|c|c|}
\hline International Differential & $\begin{array}{c}\text { Isolate 1 obtained from } \\
\text { Sakha104 }\end{array}$ & $\begin{array}{c}\text { Isolate 1 obtained from } \\
\text { Sakha101 }\end{array}$ \\
\hline Raminad str.3 & $\mathrm{R}$ & $\mathrm{R}$ \\
Zenith & $\mathrm{S}$ & $\mathrm{R}$ \\
NP-125 & $\mathrm{MR}$ & $\mathrm{R}$ \\
Usen & $\mathrm{S}$ & $\mathrm{R}$ \\
Dular & $\mathrm{R}$ & $\mathrm{R}$ \\
Kanto & $\mathrm{MR}$ & $\mathrm{MR}$ \\
Ci 8970s & $\mathrm{S}$ & $\mathrm{S}$ \\
Calora & $\mathrm{HS}$ & $\mathrm{S}$ \\
\hline Race & IB 45 & IG 1 \\
\hline
\end{tabular}

R = Resistant, MR= Moderately Resistant, $\mathrm{S}=$ Susceptible, HS= Highly Susceptible

\subsection{Field evaluation:}

The present study revealed that nitrogen fertilization (FYM and urea) at different rates had a significant effect on blast disease of rice cultivars. Data presented in Table (3) showed that neither leaf nor panicle blast infections was detected on Giza 177, Giza 178 and Giza 181, while Giza 171 was the highest infected cultivar, followed by Giza 176 while Sakha 104 and Sakha 101 showed a few type 4 lesions in some plots as a result to the application of high rates of FYM and urea. The highest infection was recorded when nitrogen was applied at the rate of $80 \mathrm{~kg} \mathrm{~N}$ urea combined with $30 \mathrm{~m}^{3}$ FYM / fed., followed by $60 \mathrm{~kg} \mathrm{~N}$ urea / fed and then $20 \mathrm{~m}^{3} \mathrm{FYM} / \mathrm{fed}$. The lowest infection resulted from the application of $10 \mathrm{~m}^{3} \mathrm{FYM}+20 \mathrm{~kg} \mathrm{~N}$ urea / fed followed by $40 \mathrm{~kg} \mathrm{~N}$ urea / fed. However, all fertilizer treatments induced higher blast infection compared with untreated plots. On the other hand, no blast infection was found on the other tested cultivars under all rates and combinations of fertilizers. 
Table (3): Effect of mineral nitrogen, farmyard manure and their combinations on susceptible rice varieties infection severity with Pyricularia grisea

\begin{tabular}{|l|c|c|c|c|}
\hline \multirow{2}{*}{ Treatment } & \multicolumn{2}{|c|}{ Leaf infection severity } & \multicolumn{2}{c|}{ Panicle infection severity } \\
\cline { 2 - 5 } & $\mathbf{2 0 0 4}$ & $\mathbf{2 0 0 5}$ & $\mathbf{2 0 0 4}$ & $\mathbf{2 0 0 5}$ \\
\hline Main effect & & & & \\
G 171 & 25.53 & 7.94 & 3.26 & 21.03 \\
G 176 & 10.20 & 6.66 & 2.70 & 3.27 \\
Sakha 101 & trace & trace & trace & trace \\
Sakha 104 & trace & trace & trace & trace \\
L.S.D. 5\% & 0.524 & 1.959 & 0.301 & 10.029 \\
Sub effect & & & & \\
$30 \mathrm{~m}^{3} \mathrm{FYM} \mathrm{/}$ & 24.00 & 7.40 & 4.70 & 17.10 \\
$80 \mathrm{~kg} \mathrm{~N} \mathrm{urea} \mathrm{/} \mathrm{f}$ & 32.50 & 12.60 & 5.14 & 21.00 \\
$20 \mathrm{~m}^{3} \mathrm{FYM} \mathrm{/} \mathrm{f}$ & 20.84 & 7.81 & 2.94 & 11.69 \\
$60 \mathrm{~kg} \mathrm{~N} \mathrm{urea} \mathrm{/} \mathrm{f}$ & 21.84 & 8.84 & 2.85 & 15.49 \\
$10 \mathrm{~m}^{3} \mathrm{FYM} \mathrm{+} \mathrm{20} \mathrm{kg} \mathrm{N}$ & 10.34 & 6.43 & 2.29 & 7.70 \\
$40 \mathrm{~kg} \mathrm{~N} \mathrm{urea} \mathrm{/} \mathrm{f}$ & 13.50 & 4.91 & 2.35 & 7.91 \\
Control (untreated) & 2.05 & 3.11 & 0.63 & 4.18 \\
L.S.D. 5\% & 1.277 & 0.744 & 1.002 & 4.468 \\
\hline
\end{tabular}

Data in Table (3) show that leaf infection was higher in 2004 season than in 2005 season, but a reverse situation was obtained with panicle infection. These results agree with those of Atkins (1974) and Kim (1986) who reported that high nitrogen levels always increase blast susceptibility. Elkazaz et al. (1997) found that the higher rates of organic or inorganic manure was accompanied with greater blast infection.

\section{White tip nematode:}

Data in Table (4) showed that the highest infection severity with white tip nematode was detected on Giza 171 (25.14), Giza 177 (5.79), Sakha 101 (2.36), Giza 176 (1.54), Giza 178 (0.86) and Giza 181 (0.46), whereas almost no infection was found on Sakha 104 cultivar. Increasing rates of organic and inorganic nitrogen led to an increase in cultivar susceptibility to white tip nematode. The highest infection was found at $30 \mathrm{~m}^{3} \mathrm{FYM}, 80 \mathrm{~kg} \mathrm{~N}$ urea/fed, $20 \mathrm{~m}^{3} \mathrm{FYM} / \mathrm{fed}$ and $60 \mathrm{~kg} \mathrm{~N}$ urea, while the lowest infection was found with $40 \mathrm{~kg} \mathrm{~N} / \mathrm{fed}$ (3.07) followed by $10 \mathrm{~m}^{3} \mathrm{FYM}+20 \mathrm{~kg} \mathrm{~N}$ urea / fed (3.90) (Table 4). In 2005 season (Table 5), Giza 171 was the highest infected cultivar (29.89) followed by Giza 177 (9.00), Sakha 101 (8.50), Giza 176 (2.12), Giza 181 (1.54) and Giza 178 (0.93), whereas the lowest infection was found on Sakha 104 (0.27). Sivakumar (1989) reported that out of 187 rice cultivars and varieties screened to white tip nematode, $A$. besseyi, TPS-1, TPS-2, AS19903, HKR-1, PTB-1, PTB-4 and Madhuri were moderately resistant. Popova et al.. (1989) evaluated more than 200 rice collection and samples. $92 \%$ of the rice hybrids and varieties were highly susceptible to $A$. besseyi, highlighting the need for the inclusion of resistant forms into the selection process. Five highly resistant collection samples were identified for further study. Silveira et al.. (1990) reported that the lines LS 85-10, 81-22, 82-279, 81$67,8-55,82-72,82-76$ and $82-8$ of rice were considered tolerant to $A$. besseyi. The lines LS 82-52, 79-188, 84-242 and LS 81-25 were susceptible. 
Also, increasing rates of inorganic or organic nitrogen led to an increase in susceptibility with white tip nematode infection. The application of $80 \mathrm{~kg} \mathrm{~N} / \mathrm{fed}$ of urea gave the highest infection (10.22) followed by $60 \mathrm{~kg} \mathrm{~N}$ urea / fed (8.45), $30 \mathrm{~m}^{3} \mathrm{FYm} /$ fed (8.23) and $20 \mathrm{~m}^{3} \mathrm{FYM} / \mathrm{fed}$ (7.22). The lowest infection was found at the rate of $10 \mathrm{~m}^{3} \mathrm{FYM} / \mathrm{fed}+20 \mathrm{~kg} \mathrm{~N}(6.22)$ and at recommended dose of nitrogen $40 \mathrm{~kg} \mathrm{~N} /$ fed (6.43).

Table (4): Effect of mineral nitrogen, farmyard manure and their combinations on infection severity with white tip nematode in commercial rice varieties-2004 season

\begin{tabular}{|c|c|c|c|c|c|c|c|c|}
\hline Treatment & $\begin{array}{c}\text { Giza } \\
171\end{array}$ & $\begin{array}{c}\text { Giza } \\
176\end{array}$ & $\begin{array}{c}\text { Giza } \\
177\end{array}$ & $\begin{array}{c}\text { Giza } \\
178\end{array}$ & $\begin{array}{c}\text { Giza } \\
181\end{array}$ & $\begin{array}{c}\text { Sakha } \\
101\end{array}$ & $\begin{array}{c}\text { Sakha } \\
104\end{array}$ & $\begin{array}{c}\text { S. } \\
\text { Mean }\end{array}$ \\
\hline $30 \mathrm{~m}^{3} \mathrm{FYM}$ & 44.50 & 1.75 & 10.50 & 1.50 & 0.75 & 3.75 & 0.01 & 8.96 \\
\hline & & 2.75 & & 1.75 & 1.25 & & 0.01 & 7.40 \\
\hline & & 2.00 & & 1.5 & 0.5 & 2.7 & 0.01 & 5.93 \\
\hline & 2 & 2.25 & 6.25 & 1.25 & 0.75 & 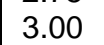 & 0.01 & 5.43 \\
\hline $\mathrm{kg} \mathrm{N} / \mathrm{fed}$ & 21.00 & 0.75 & & & & & 0.01 & 3.90 \\
\hline & 18.2 & 0.75 & 1.75 & 0.01 & 0.01 & 0.75 & 0.01 & 3.07 \\
\hline Control (untreated) & & 0.50 & & & & 0.25 & 0.01 & 1.57 \\
\hline $1 M$ & 25.14 & 1.54 & 5.79 & 0.86 & 0.46 & 2.36 & 0.01 & \\
\hline
\end{tabular}

Table (5): Effect of mineral nitrogen, farmyard manure and their combinations of infection severity with white tip nematode infection in commercial rice varieties- 2005 season

\begin{tabular}{|l|c|c|c|c|c|c|c|c|}
\hline Treatment & $\begin{array}{c}\text { Giza } \\
\mathbf{1 7 1}\end{array}$ & $\begin{array}{c}\text { Giza } \\
\mathbf{1 7 6}\end{array}$ & $\begin{array}{c}\text { Giza } \\
\mathbf{1 7 7}\end{array}$ & $\begin{array}{c}\text { Giza } \\
\mathbf{1 7 8}\end{array}$ & $\begin{array}{c}\text { Giza } \\
\mathbf{1 8 1}\end{array}$ & $\begin{array}{c}\text { Sakha } \\
\mathbf{1 0 1}\end{array}$ & $\begin{array}{c}\text { Sakha } \\
\mathbf{1 0 4}\end{array}$ & $\begin{array}{c}\text { S. } \\
\text { Mean }\end{array}$ \\
\hline $30 \mathrm{~m}^{3} \mathrm{FYM} / \mathrm{fed}$ & 33.00 & 2.75 & 10.00 & 2.05 & 1.50 & 8.00 & 0.30 & 8.23 \\
$80 \mathrm{~kg} \mathrm{~N} \mathrm{urea} \mathrm{/} \mathrm{fed}$ & 40.50 & 4.75 & 10.25 & 2.06 & 2.25 & 11.00 & 0.73 & 10.22 \\
$20 \mathrm{~m}^{3} \mathrm{FYM} \mathrm{/} \mathrm{fed}$ & 31.75 & 0.25 & 9.00 & 1.24 & 1.75 & 6.25 & 0.25 & 7.22 \\
$60 \mathrm{~kg} \mathrm{~N} \mathrm{urea} \mathrm{/} \mathrm{fed}$ & 35.25 & 3.35 & 8.50 & 0.72 & 2.50 & 9.75 & 0.53 & 8.45 \\
$10 \mathrm{~m}^{3} \mathrm{FYM} \mathrm{+} \mathrm{20} \mathrm{kg} \mathrm{N/fed}$ & 22.25 & 2.25 & 8.00 & 0.50 & 0.50 & 9.25 & 0.01 & 6.22 \\
$40 \mathrm{~kg} \mathrm{~N} \mathrm{urea} \mathrm{/} \mathrm{fed}$ & 24.50 & 1.25 & 10.50 & 0.25 & 0.25 & 7.75 & 0.01 & 6.43 \\
Control (untreated) & 22.00 & 0.24 & 6.75 & 0.01 & 0.01 & 7.50 & 0.01 & 5.25 \\
\hline M. Mean & 29.89 & 2.12 & 9.00 & 0.93 & 1.54 & 8.50 & 0.27 & \\
\hline
\end{tabular}

L.S.D. 5\% Main 2.144 $\quad$ Sub 1.587 $\quad$ Interaction 4.119

Data in Table (6) show the numbers of nematode larvae per 10 panicles. Giza 171 cultivar contained the highest population of larvae, followed by Giza 177, and then Sakha 101. The lowest populations were detected in varieties Sakha 104, Giza 181 and Giza 178. On the other hand, $30 \mathrm{~m}^{3} \mathrm{FYM}$ induced the highest number of nematode larvae, followed by 80 $\mathrm{kg} \mathrm{N}, 20 \mathrm{~m}^{3} \mathrm{FYM}$, while the least number was that of $10 \mathrm{~m}^{3} \mathrm{FYM}+20 \mathrm{~kg} \mathrm{~N}$ and $40 \mathrm{~kg} \mathrm{~N}$.

It was observed generally that the lowest disease infection severity (blast and white tip nematode) were obtained from unfertilized plots compared with other fertilizer treatments, but in the same time the yield was highly reduced. 
Table (6): Number of nematode larvae (per 10 panicles) as affected by fertilization treatments

\begin{tabular}{|l|c|c|c|c|c|c|c|c|}
\hline Treatment & $\begin{array}{c}\text { Giza } \\
\mathbf{1 7 1}\end{array}$ & $\begin{array}{c}\text { Giza } \\
\mathbf{1 7 6}\end{array}$ & $\begin{array}{c}\text { Giza } \\
\mathbf{1 7 7}\end{array}$ & $\begin{array}{c}\text { Giza } \\
\mathbf{1 7 8}\end{array}$ & $\begin{array}{c}\text { Giza } \\
\mathbf{1 8 1}\end{array}$ & $\begin{array}{c}\text { Sakha } \\
\mathbf{1 0 1}\end{array}$ & $\begin{array}{c}\text { Sakha } \\
\mathbf{1 0 4}\end{array}$ & $\begin{array}{c}\text { S. } \\
\text { Mean }\end{array}$ \\
\hline $30 \mathrm{~m}^{3} \mathrm{FYM} / \mathrm{fed}$ & 28 & 5 & 12 & 3 & 3 & 6 & 2 & 8.43 \\
$80 \mathrm{~kg} \mathrm{~N}$ urea / fed & 24 & 4 & 11 & 2 & 2 & 5 & 1 & 7.00 \\
$20 \mathrm{~m}^{3} \mathrm{FYM} / \mathrm{fed}$ & 8 & 3 & 9 & 2 & 2 & 5 & 1 & 4.29 \\
$60 \mathrm{~kg} \mathrm{~N} \mathrm{urea} \mathrm{/} \mathrm{fed}$ & 6 & 4 & 8 & 2 & 2 & 5 & 0.01 & 3.86 \\
$10 \mathrm{~m}^{3} \mathrm{FYM}+20 \mathrm{~kg} \mathrm{~N} /$ fed & 4 & 2 & 6 & 1 & 1 & 4 & 0.01 & 2.57 \\
$40 \mathrm{~kg} \mathrm{~N} \mathrm{urea} \mathrm{/} \mathrm{fed}$ & 5 & 2 & 4 & 0.01 & 0.01 & 2 & 0.01 & 1.86 \\
Control (untreated) & 4 & 2 & 4 & 0.01 & 0.01 & 2 & 0.01 & 1.71 \\
\hline M. Mean & 11.29 & 3.14 & 7.71 & 1.43 & 1.43 & 4.14 & 0.57 & \\
\hline
\end{tabular}

\section{Rice stem borer infestation:}

The effects of applying mineral nitrogenous fertilizer, farmyard manure (FYM), and their combinations on levels of rice stem borer infestation in seven commercial rice cultivars are presented in Tables ( 7 and 8 ).

In 2004 (Table7), the highest borer infestation $(7.09 \%$ white head) was recorded in plots having the highest rate of mineral nitrogen $(80 \mathrm{~kg}$ urea / fed). This level proved to be significantly different from any other treatment. The second rank of borer infestation was also recorded for mineral nitrogen; $5.56 \%$ white head at $60 \mathrm{~kg}$ urea / fed. However, this borer level was significantly the same of applying $40 \mathrm{~kg}$ urea / fed (4.85\% white head). The three remaining treatments having only FYM, or FYM manure combined with mineral nitrogen induced relatively lower stem borer infestations as compared with only mineral nitrogen. These levels, with no significant differences, were 4.16, 4.37 and $4.34 \%$ white heads for 20 tons FYM, 30 tons FYM, and $20 \mathrm{~kg}$ urea combined with 10 tons FYM / feddan, respectively.

Table (7): Effect of mineral nitrogenous fertilizer and farmyard manure on rice stem borer infestation of rice varieties $\mathbf{- 2 0 0 4}$

\begin{tabular}{|c|c|c|c|c|c|c|c|c|}
\hline \multirow{2}{*}{$\begin{array}{l}\text { Treatment } \\
\text { (per feddan) }\end{array}$} & \multicolumn{8}{|c|}{ Cultivar } \\
\hline & Giza 171 & Giza 176 & Giza 177 & Giza 178 & Giza 181 & $\begin{array}{c}\text { Sakha } \\
101\end{array}$ & $\begin{array}{c}\text { Sakha } \\
104 \\
\end{array}$ & Overall \\
\hline $\begin{array}{l}\text { Urea } 40 \mathrm{~kg} \\
\text { Urea } 60 \mathrm{~kg} \\
\text { Urea } 80 \mathrm{~kg} \\
\text { FYM } 20 \mathrm{~m}^{3} \\
\text { FYM } 30 \mathrm{~m}^{3} \\
\text { Urea } 20 \mathrm{~kg}+ \\
\text { FYM } 10 \mathrm{~m}^{3}\end{array}$ & $\begin{array}{l}4.33 \\
5.28 \\
6.66 \\
4.13 \\
4.16 \\
5.12\end{array}$ & $\begin{array}{l}2.18 \\
2.01 \\
2.30 \\
2.00 \\
2.20 \\
3.38\end{array}$ & $\begin{array}{l}6.38 \\
7.49 \\
8.01 \\
5.20 \\
6.50 \\
4.40\end{array}$ & $\begin{array}{c}7.18 \\
9.13 \\
12.15 \\
6.50 \\
8.72 \\
6.15\end{array}$ & $\begin{array}{l}2.90 \\
2.98 \\
3.23 \\
1.99 \\
3.11 \\
1.95\end{array}$ & $\begin{array}{l}6.80 \\
6.88 \\
8.15 \\
5.53 \\
5.90 \\
5.11\end{array}$ & $\begin{array}{l}4.18 \\
5.14 \\
9.10 \\
3.78 \\
6.61 \\
4.28\end{array}$ & $\begin{array}{l}4.85 \mathrm{bc} \\
5.56 \mathrm{~b} \\
7.09 \mathrm{a} \\
4.16 \mathrm{c} \\
4.37 \mathrm{c} \\
4.34 \mathrm{c}\end{array}$ \\
\hline Control & 2.64 & 2.00 & 3.59 & 6.20 & 2.55 & 3.28 & 2.16 & \\
\hline Overall av. & $4.95 \mathrm{~cd}$ & $2.35 \mathrm{~d}$ & $6.33 \mathrm{~b}$ & $8.31 \mathrm{a}$ & $2.69 \mathrm{~d}$ & $6.40 \mathrm{~b}$ & $5.52 \mathrm{c}$ & \\
\hline
\end{tabular}

The results obtained in 2005 rice season (Table 8) were similar to those of 2004. The highest borer infestation $(6.51 \%$ white head) was detected in plots fertilized with $80 \mathrm{~kg}$ urea / fed, while the lowest infestation was recorded in plots having 20 tons FYM (4.18\% white head).

Thus, it could be concluded that higher mineral nitrogenous fertilization encouraged the rice stem borer more than the organic nitrogenous fertilization (FYM) did. 
Table (8): Effect of mineral nitrogenous fertilizer and farmyard manure on rice stem borer infestation of rice varieties -2005

\begin{tabular}{|c|c|c|c|c|c|c|c|c|}
\hline \multirow{2}{*}{$\begin{array}{l}\text { Treatment } \\
\text { (per feddan) }\end{array}$} & \multicolumn{8}{|c|}{ Cultivar } \\
\hline & Giza 171 & Giza 176 & Giza 177 & Giza 178 & Giza 181 & $\begin{array}{c}\text { Sakha } \\
101\end{array}$ & $\begin{array}{c}\text { Sakha } \\
104\end{array}$ & Overall \\
\hline \begin{tabular}{|l|} 
Urea $40 \mathrm{~kg}$ \\
Urea $60 \mathrm{~kg}$ \\
Urea $80 \mathrm{~kg}$ \\
FYM $20 \mathrm{~m}^{3}$ \\
FYM $30 \mathrm{~m}^{3}$ \\
Urea $20 \mathrm{~kg}+$ \\
FYM $10 \mathrm{~m}^{3}$ \\
\end{tabular} & $\begin{array}{l}3.90 \\
4.65 \\
4.66 \\
2.89 \\
3.74 \\
3.07\end{array}$ & $\begin{array}{l}1.96 \\
1.41 \\
2.07 \\
1.60 \\
1.76 \\
3.04\end{array}$ & $\begin{array}{l}5.10 \\
6.74 \\
7.21 \\
5.15 \\
5.20 \\
3.87\end{array}$ & $\begin{array}{c}6.46 \\
8.22 \\
10.94 \\
7.15 \\
8.89 \\
7.80\end{array}$ & $\begin{array}{l}2.81 \\
2.68 \\
4.15 \\
2.18 \\
3.20 \\
2.95\end{array}$ & $\begin{array}{l}6.12 \\
5.50 \\
6.52 \\
4.98 \\
6.46 \\
5.67\end{array}$ & $\begin{array}{c}5.02 \\
5.65 \\
10.01 \\
5.29 \\
8.59 \\
7.70\end{array}$ & $\begin{array}{l}4.48 \mathrm{c} \\
4.98 \mathrm{c} \\
6.51 \mathrm{a} \\
4.18 \mathrm{~d} \\
5.41 \mathrm{~b} \\
4.87 \mathrm{c}\end{array}$ \\
\hline Control & 2.26 & 1.09 & 3.50 & 4.18 & 2.77 & 2.20 & 2.53 & \\
\hline Overall av. & $3.82 \mathrm{~d}$ & $1.97 \mathrm{e}$ & $5.55 \mathrm{c}$ & $8.24 \mathrm{a}$ & $3.00 \mathrm{~d}$ & $5.88 \mathrm{c}$ & $7.04 \mathrm{~b}$ & \\
\hline
\end{tabular}

Similar results were obtained by Subramanian et al. (1977) and Sherif (1980) who detected higher stem borer infestation with higher rates of nitrogen. The better growth of rice plants due to higher rates of nitrogen leads to softer tissues and quicker penetration by first instar borer larvae. Natarajan and Pillai (1985) explained that the quicker penetration allows more borer larvae to escape natural enemies, and thus enhances the borer infestation. Sasamoto (1957) and El-Samahy (2002) confirmed that silica hardens rice stems making the crop resistant to stem borer larval feeding. This phenomenon may clarify why the application of FYM, that should have plant residues containing silica, tended to reduce the borer infestation in the current investigation.

On the other hand, the most sensitive cultivar to borer infestation in this study was Giza 178, followed by Sakha 102 and Giza 182. The most resistant cultivar to the insect were Giza 176 and Sakha 101. The remaining evaluated cultivars exhibited intermediate levels of borer infestation.

\section{Grain yield:}

Data presented in Table (9) indicated that the highest grain yield in 2004 season was obtained from Giza 178 followed by Sakha 104, Sakha 101, Giza 177 and Giza 171 while Giza 181 and Giza 176 yielded lowest. Concerning fertilization, $30 \mathrm{~m}^{3} \mathrm{FYM}$ produced the highest yield, followed by $60 \mathrm{~kg} \mathrm{~N}, 10 \mathrm{~m}^{3} \mathrm{FYM}+20 \mathrm{~kg}$ urea, $20 \mathrm{~m}^{3} \mathrm{FYM}, 80 \mathrm{~kg} \mathrm{~N}$ urea / fed and $40 \mathrm{~kg}$ $\mathrm{N}$ urea / fed.

Data presented in Table (10) indicated that the highest grain yield in 2005 was obtained from Sakha 101 followed by Sakha 104, Giza 176, Giza 178 and Giza 177, respectively, while Giza 171 yielded lowest. Concerning nitrogen fertilization, the yield was ordered decreasing as $80 \mathrm{~kg} \mathrm{~N}$ urea / fed, $30 \mathrm{~m}^{3} \mathrm{FYM} / \mathrm{f}, 20 \mathrm{~m}^{3} \mathrm{FYM}$ and $60 \mathrm{~kg} \mathrm{~N}$ urea / f, respectively, while lowest grain yield was at $40 \mathrm{~kg} \mathrm{~N}$ urea / fed.

These results are agree with those of Chakraborty et al. (1988), Rajput and Wass (1991) and Budhar et al. (1991) who reported that grain yield of rice was higher significantly by farmyard manure and green manures over control. Thakur et al. (1995) reported that yields of rice grain and straw increased significantly due to the application of organic manures. 
Table (9): Effect of mineral nitrogen, farmyard manure and their combination on rice yield of commercial varieties -2004 season.

\begin{tabular}{|c|c|c|c|c|c|c|c|c|}
\hline Treatment & $\begin{array}{c}\text { Giza } \\
171\end{array}$ & $\begin{array}{c}\text { Giza } \\
176\end{array}$ & $\begin{array}{c}\text { Giza } \\
177\end{array}$ & $\begin{array}{c}\text { Giza } \\
178\end{array}$ & $\begin{array}{c}\text { Giza } \\
181\end{array}$ & $\begin{array}{c}\text { Sakha } \\
101\end{array}$ & $\begin{array}{c}\text { Sakha } \\
104\end{array}$ & $\begin{array}{c}\text { S. } \\
\text { Mean }\end{array}$ \\
\hline $\begin{array}{l}30 \mathrm{~m}^{3} \text { FYM / fed } \\
80 \mathrm{~kg} \mathrm{~N} \mathrm{urea} \mathrm{/} \mathrm{fed} 20 \mathrm{~m}^{3} \text { FYM / fed } \\
60 \mathrm{~kg} \mathrm{~N} \mathrm{urea} \mathrm{/} \mathrm{fed} \\
10 \mathrm{~m}^{3} \text { FYM + } 20 \mathrm{~kg} \\
\mathrm{~N} / \mathrm{fed} \\
40 \mathrm{~kg} \mathrm{~N} \text { urea / fed } \\
\text { Control (untreated) }\end{array}$ & $\begin{array}{l}3.23 \\
3.26 \\
3.19 \\
3.37 \\
3.20 \\
3.20 \\
2.44\end{array}$ & $\begin{array}{l}3.49 \\
3.25 \\
3.33 \\
3.41 \\
3.24 \\
3.26 \\
2.66\end{array}$ & $\begin{array}{l}3.55 \\
3.34 \\
3.46 \\
3.71 \\
3.46 \\
3.41 \\
3.11\end{array}$ & $\begin{array}{l}4.07 \\
3.76 \\
4.01 \\
3.88 \\
4.25 \\
3.77 \\
3.34\end{array}$ & $\begin{array}{l}3.46 \\
3.50 \\
3.43 \\
3.67 \\
3.42 \\
3.40 \\
3.11\end{array}$ & $\begin{array}{l}3.92 \\
3.92 \\
3.67 \\
3.63 \\
3.66 \\
3.60 \\
3.22\end{array}$ & $\begin{array}{l}3.75 \\
3.56 \\
3.75 \\
3.67 \\
4.03 \\
3.71 \\
3.38\end{array}$ & $\begin{array}{l}3.64 \\
3.51 \\
3.55 \\
3.62 \\
3.61 \\
3.48 \\
3.04\end{array}$ \\
\hline M. Mean $(\mathrm{t} / \mathrm{fed})$ & 3.12 & 3.23 & 3.43 & 3.87 & 3.43 & 3.66 & 3.69 & \\
\hline
\end{tabular}

Table (10): Effect of mineral nitrogen, farmyard manure and their combination on rice yield of commercial varieties - 2005 season.

\begin{tabular}{|l|c|c|c|c|c|c|c|c|}
\hline Treatment & Giza & Giza & Giza & Giza & Giza & Sakha & Sakha & S. Mean \\
& $\mathbf{1 7 1}$ & $\mathbf{1 7 6}$ & $\mathbf{1 7 7}$ & $\mathbf{1 7 8}$ & $\mathbf{1 8 1}$ & $\mathbf{1 0 1}$ & $\mathbf{1 0 4}$ & \\
\hline $30 \mathrm{~m}^{3} \mathrm{FYM} / \mathrm{fed}$ & 2.74 & 3.68 & 3.45 & 3.89 & 3.78 & 4.10 & 4.21 & 3.69 \\
$80 \mathrm{~kg} \mathrm{~N}$ urea / fed & 2.70 & 3.92 & 3.99 & 3.67 & 4.20 & 4.30 & 4.00 & 3.82 \\
$20 \mathrm{~m}^{3} \mathrm{FYM} / \mathrm{fed}$ & 2.76 & 3.81 & 3.42 & 3.68 & 3.64 & 4.00 & 4.10 & 3.63 \\
$60 \mathrm{~kg} \mathrm{~N} \mathrm{urea} \mathrm{/} \mathrm{fed}$ & 2.72 & 3.75 & 3.76 & 3.49 & 3.85 & 3.97 & 3.67 & 3.60 \\
$10 \mathrm{~m}^{3} \mathrm{FYM}+20 \mathrm{~kg} \mathrm{~N} / \mathrm{fed}$ & 3.12 & 3.75 & 3.73 & 3.69 & 3.43 & 3.76 & 3.75 & 3.56 \\
$40 \mathrm{~kg} \mathrm{~N}$ urea / fed & 2.32 & 3.28 & 3.04 & 3.06 & 3.23 & 3.48 & 3.53 & 3.10 \\
Control (untreated) & 1.91 & 2.21 & 1.99 & 2.26 & 2.17 & 2.74 & 2.41 & 2.24 \\
M. Mean (t / fed) & 2.67 & 3.49 & 3.34 & 3.39 & 3.04 & 3.77 & 3.67 & \\
\hline
\end{tabular}

\section{REFERENCES}

Abdel-Hak T. M.; J.P.Jones and M.R.Sehly (1982). Plant pathology program, blast loss assessment. Proceedings of First National Rice Institute Conference, Feb., 6-10, 117-129, Cairo, Egypt.

Atikins, J.G. (1974). Rice disease of the Americas. A review of literature, Agriculture Handbook. N. 448. Agric Research Service. U.S. Depart. of Agric.

Budhar, M.N.; S.P. Palaniappan and A. Ranga Samy (1991). Effect of farm wastes and green manures. Indian Journal of Agronomy, 36 (2): 251252.

Chakeaborty P.K.L.N. Manaal (1988). Organic and chemical sources of nitrogen its effect on nitrogen transformation and rice productivity under submerged conditions. J.Agric.Sci Camb, 111: 91-94.

Chu, L.; H.L. Hiao; K.S. Tsai and C.C. YU (1978). Soil nutrition status under rice-wheat rotation and responses of rice to fertilizer in Suchow district, Acta Pedol Sin. 15:126-137.

El-Kazzaz, M.K.; Fawzia M. Fadel; M.A. Gabr and E.A.S.Badr (1997). Relation between the application of different organic manures and rice blast disease development. $7^{\text {th }}$ Nat. Conf. of Pest \& Dis. of vegetables and fruits in Egypt, Proceedings Volume 1 Ismailia, 25-26 November. 
El-Kazzaz, M.K.; M.R. Sehly; Z.H. Osman and S.A. Badr (1990). Evaluation of some rice cultivars and lines to rice blast disease. Agricultural Research Review, 68 (3): 481-490.

El-Kazzaz, M.K.; M.R. Shehly, Z.H. Osman and E.A.S. Badr (1989). Evaluation of some rice cultivars and lines to rice blast disease under Egyptian conditions. Agric. Res. Review, 68 (3): 481-485.

El-Refaei, M.I.; M.A. Kararah; M.A. Afifi and M.M. Ragab (1985). Effect of nitrogenous fertilizers and seedling density on rice blast disease incidence. Egyptian Journal of Phytopath, 14 (42): 19-25.

El-Samahy, M.F. (2002). Studies on the rice stem borer, Chilo agamemnon Bles. M.Sc. Thesis, Fac. Agric., Kafr El-Sheikh, Tanta Univ.

Horino, O.; F. El-Nemr; M. Yousef and H. Niki (1990). Factors of the rice blast outbreak in Nile Delta, Egypt. Jarg, Japan Agricultural Res. Quarterly, 23(3): 176-181.

IRRI, International Rice Research Institute (1996). Standard evaluation system for rice $3^{\text {rd }}$ ed. Los Banos, Philippines.

Isa, A.L. (1989). Integrated pest management in Egypt. In: Rice Farming Systems, New Directions. Proceedings of an International Symposium 31 January - 5 February, 1987. Rice Research and Training Center, Sakha, Egypt. Edited by IRRI.

Kin, Choong-Hop (1986). Effect of mineral nutrition under different water management practices on development of rice blast. Ph.D. Thesis, Louisiana State University and Agricultural and Mechanical College. $170 \mathrm{p}$.

Magdoff, F. and H. van Es (2000). Bulding soils for better crops. SARE, Washington DC.

Meyer, G.A. (2000). Interactive effects of soil fertility and herbivory on Brassica nigra. Oikos 22: 433-441.

Natarajan, L. and S. Janardhanan Pillai (1985). The role of crop nutrients in pest incidence. In: Role of Potassium Crop Resistance to Insect Pests. Potash Research Institute of India. Research Review Series 3, Gurgaon, Haryama, India, pp. 35-41.

Popova, M.B., Myrzin, A.S. and Dzyuba, V.A. (1989). Estimation of collection and selection samples of rice for resistance to the rice leaf nematode. Byulleten' Vsesoyuznogo Instituta Gel'mintologii 50: 52-58.

Rajput A.L. and A.S. Wass (1991). Contribution of organic materials to nitrogen economy in rice (Oryza sativa. L.) production. Indian J. Agric. 36 (3): 455-456.

Sasamoto, K. (1957). Studies on the relation between the silica content in the rice plant and insect pests. Botyu-Kogaku 22: 159-164.

Sehly, M.R. (1982). Physiological and epidemiological studies on Pyricularia oryzae Cav. inciting rice blast disease. Ph.D. Thesis , Fac. Agric, Menofiya Univ.

Sharma A.R. and B. N. Mittra (1988). Effect of combinations of organic materials and nitrogen fertilizer on growth, yield and nitrogen uptake of rice. J.Agric.Sci Camb. 111: 495-501.

Sharma A.R. and B. N. Mittra (1991). Effect of different rates of application of organic and nitrogen fertilizers in rice based cropping system. Journal of Agricultural Science, Cambridge, 117: 313-318. 
Shatla, M.N; M. Nazium; A.M. Basiony; A.T. Abou El-Ghar; M.R. Sehly and Z. El-Shennawy (1983). Effect of nitrogen fertilization on the physiology of rice plant resistance to blast. Menufiya Journal of Agric. Res., (6) :6174.

Sherif, M. R.(1980). Studies on the rice borer attacking rice plants in Kafr ElSheikh region. M. Sc. Thesis, Fac. Agric., Tanta Univ.

Silveira, S. G. P. da; Curi, S. M. and O. Tisseli (1990). Reaction of rice breeding lines to seed nematode Aphelenchoides besseyi Christie, 1942. Nematologia Brasileira, 14, 54-60.

Sivakumar, C. V. (1988). A new method of culturing Aphelenchoides besseyi. Indian J. Nemato., 18 (1):119.

Subramanian, V.; M. Mani and V. D. Guruswamy Roja (1977). Effect of graded levels of nitrogen on the incidence of rice stem borer, Tryporyza incertulas Walk. Sci. and Cult. 43 (5): 222-223.

Thakur, R.C.; A.D. Bindra; R.D. Sood and M. Bhargava (1995). Effect of fertilizer application and green-manuring on physico-chemical properties of soil and grain yield in rice (Oryza sativa) wheat (Triticum sativum), crop sequence. Indian J. Agron. 40 (1): 4-13.

Townsend, G.R. and J.W. Heuberger (1943). Methods for estimating losses caused by disease in fungicide experiments. Plant Disease Report, 27 (17): 340-343.

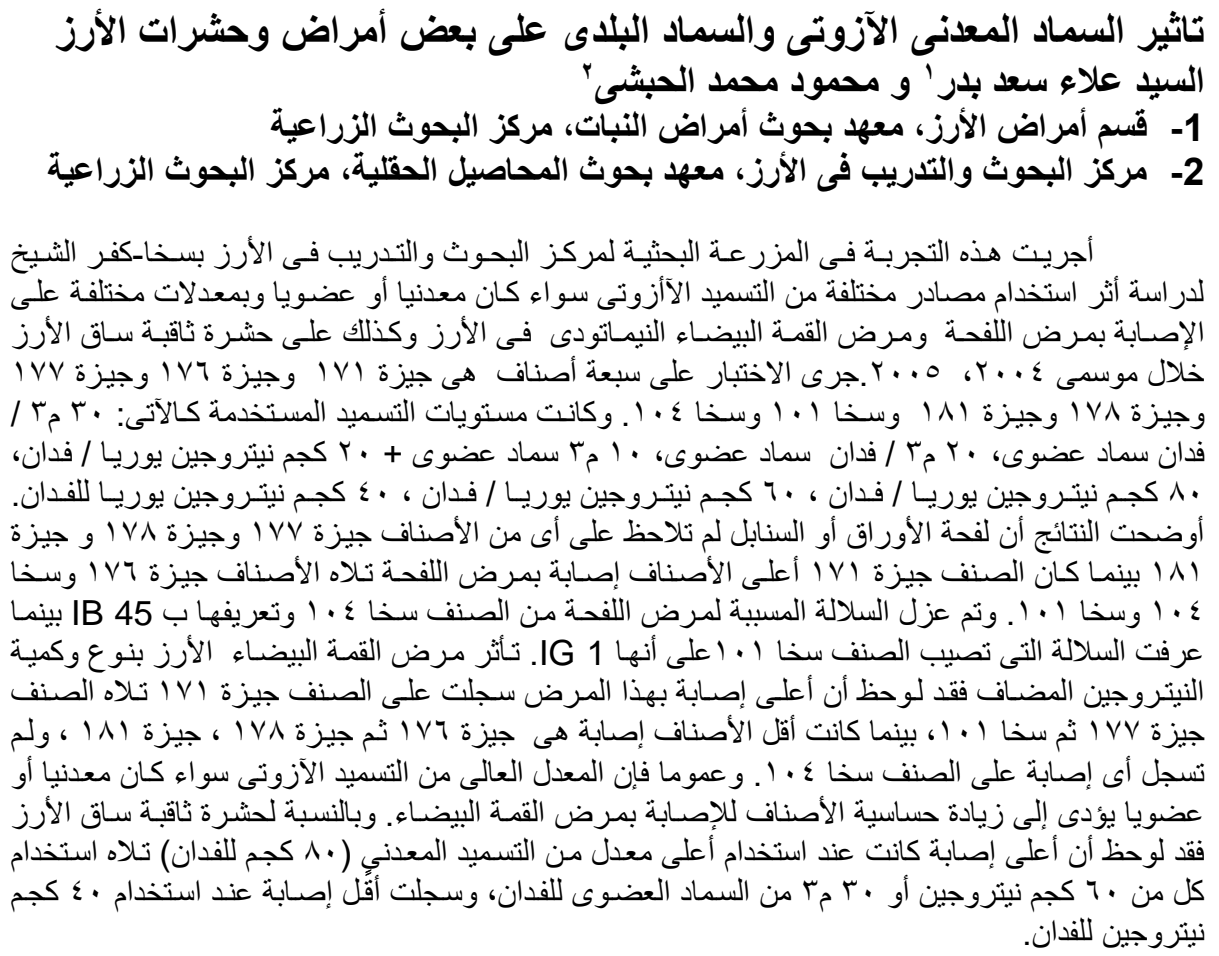

